\title{
PEMBELAJARAN SEJARAH MENGGUNAKAN METODE PEMECAHAN MASALAH (PROBLEM SOLVING) DALAM MELATIH KETERAMPILAN BERFIKIR KRONOLOGIS PESERTA DIDIK
}

\author{
Jamaludin \\ Program Studi Pendidikan Sejarah FKIP Universitas Lambung Mangkurat \\ Banjarmasin \\ Email: 1710111210009@mhs.ulm.ac.id
}

\begin{abstract}
ABSTRAK: Pembelajaran sejarah sebagai salah satu mata pelajaran wajib di SMA Sederajat memiliki peran penting dalam membentuk karakter bangsa. Namun cukup disayangkan karena pembelajaran sejarah belum dilaksanakan berdasarkan konsep-konsep sejarah yang tepat dan belum dapat dimainkan perannya sebagai pembentuk karakter bangsa secara optimal secara optimal. Terdapat banyak sekali metode pembelajaran yang dapat diterapkan untuk mengoptimalkan peran pembelajaran sejarah itu sendiri, satu diantaranya adalah pemecahan masalah (problem solving).

Metode pemecahan masalah sendiri dapat digunakan oleh guru untuk melatih kemampuan berfikir kronologis peserta didik. Selain itu metode ini juga dapat melatih peserta didik untuk mencari, menemukan serta memecahkan persoalanpersoalan peristiwa sejarah. Metode pemecahan masalah ini dilakukan dengan cara ilmiah, artinya metode ini harus mengikuti kaidah keilmuan.
\end{abstract}

Kata kunci : peserta didik, pemecahan masalah dan berfikir kronologis.

\section{PENDAHULUAN}

Pembelajaran sejarah terdiri dari dua kata, yaitu pembelajaran dan sejarah. Pembelajaran adalah proses atau suatu cara yang dilakukan agar seseorang maupun sekelompok orang dapat melakukan kegiatan belajar (Arifin, 2009 dalam Susanto, Akmal 2019). Belajar sendiri menurut Ernest R. Hilgard (Suryasubrata 1984 dalam Susanto, 2019) adalah usaha yang dilakukan secara sadar sehingga menimbulkan perubahan. Heri Susanto dkk (2019.14) berpendapat bahwa Perubahan di sini berupa perubahan kognitif (pengetahuan), afektif (sikap), dan psikomotorik (keterampilan). Belajar merupakan dasar terjadinya pembelajaran, ketika seseorang atau sekelompok orang melakukan kegiatan belajar dan membagikannya satu sama lain baik di dalam maupun di luar ruangan dapat dikatakansebagai pembelajaran.

Pembelajaran sejarah merupakan bidang ilmu yang memiliki tujuan agar setiap peserta didik membangun kesadaran tentang pentingnya waktu dan tempat yang merupakan sebuah proses dari masa lampau, masa kini dan masa depan 
sehingga peserta didik sadar bahwa dirinya merupakan bagian dari bangsa Indonesia yang memiliki rasa bangga dan cinta tanah air yang dapat diimplementasikan dalam berbagai kehidupan baik nasional maupun internasional (Widja, 1989 dalam Zahro, Sumardi, \& Marjono, 2017).

Pembelajaran sejarah ini mempunyai peranan dalam upaya pembentukan karakter bangsa dan menanamkan nilai budaya. Tujuan pembelajaran sejarah adalah untuk menanamkan semangat kebangsaan, cinta tanah air, bangsa dan negara. Materi dalam pembelajaran sejarah ini mampu untuk mengembangkan potensi peserta didik untuk lebih mengenal nilai-nilai bangsa yang diperjuangkan pada masa lampau, dipertahankan, dan disesuaikan untuk masa yang kini dan dikembangkan dimasa yang akan datang, juga dalam sejarah dipaparkan mengenai berbagai peristiwa dan kejadian yang nyata yang telah terjadi dimasa lampau, bukan hanya karangan fiktif belaka, seperti kegigihan para pejuang melawan penjajah dalam mempertahankan harga diri bangsa (Kasmadi \& Hartono, 1996).

Proses belajar mengajar bukan hanya sebatas transfer informasi dari guru ke peserta didik, tetapi sebagai proses yang kompleks, peserta didik belajar dari segala sesuatu yang terjadi dalam pembelajaran. Peserta didik akan belajar ilmu terbaik ketika metodologi pengajaran memungkinkan mereka untuk terlibat secara aktif dalam kegiatan kelas. Dalam hal ini, peserta didik harus berpartisipasi aktif dalam melakukan eksperimen, melaksanakan demonstrasi, diskusi kelas dan pengalaman belajar yang relevan lainnya.Guru memiliki kewajiban untuk menekankan kepada peserta didik agar memiliki kemampuan pemecahan masalah dan berpikir kritis. (Khairani \& Safitri, 2017).

Masalah utama dalam pembelajaran pada pendidikan formal dewasa ini adalah masih rendahnya daya serap peserta didik, hal ini terjadi karena proses pembelajaran hingga dewasa ini masih memberikan dominasi guru dan tidak memberikan akses bagi anak didik untuk berkembang secara mandiri melalui penemuan dalam proses berpikirnya (Trianto, 2010). Menurut Sjamsuddin dengan belajar sejarah seseorang memperoleh pemahaman atau apresiasi tentang orang-orang, peristiwa -peristiwa atau periode-periode tertentu dari masa lalu yang dikaji. Bahwa Peserta didik memerlukan "Knowldge and reasoning skills for effective functioning in the Age" (Pengetahuan dan keterampilan-keterampilan memberi fungsi efektif dalam perkembangan kemampuan seseorang) (Sjamsudin, 2007 dalam Hudaidah, 2014).

Dalam pembelajaran sendiri pastinya perlu adanya inovasi dari guru untuk memberikan materi dan meningkatkan keterampilan berfikir kronologis, keterampilan berfikir kronologis peserta didik dapat memudahkan mereka untuk memahami kejadian ataupun runtutan sejarah di ajarkan. Terdapat banyak metode yang dapat digunakan untuk mencapai tujuan tersebut. Salah satu diantaranya adalah metode Pemecahan Masalah atau Problem Solving. 
Penerapan model yang bervariasi dan tepat dalam pembelajaran sejarah dengan mengedepankan aktivitas aktif dari mahaPeserta didik dalam seluruh proses pembelajaran akan memberi kesempatan kepada peserta didik untuk mengembangkan seluruh potensi yang dimiliki dalam pembelajaran. Melalui cara ini memunculkan aktivitas keterampilan berpikir kronologis, yang dilakukan secara sungguh-sungguh maka bentuk belajar akan beralih dari berpusat pada guru menjadi berpusat pada peserta didik. guru dapat melakukan fungsinya sebagai fasilitator, pengarah, pembimbing dan penilai terhadap proses pembelajaran dan peserta didik memanfaatkan segala potensinya dalam belajar. Sehingga akan memberikan pengalaman pada mahaPeserta didik dalam mengumpulkan, mengorganisasi dan mengklasifikasi data sejarah dengan baik.

\section{METODE PROBLEM SOLVING DALAM PEMBELAJARAN SEJARAH}

Metode pemecahan masalah adalah suatu cara pembelajaran dengan menghadapkan Peserta didik kepada suatu masalah untuk dipecahkan atau diselesaikan secara konseptual masalah terbuka dalam pembelajaran. Pemecahan masalah (problem solving) adalah penggunaan metode dalam kegiatan pembelajaran dengan jalan melatih Peserta didik menghadapi berbagai masalah baik itu masalah pribadi atau perorangan maupun masalah kelompok untuk dipecahkan sendiri atau secara bersama-sama. Metode pemecahan masalah (problem solving) juga dikenal dengan metode brainstorming, karena merupakan sebuah metode yang merangsang dan menggunakan wawasan tanpa melihat kualitas pendapat yang disampaikan oleh Peserta didik. Guru disarankan tidak berorientasi pada metode tersebut, akan tetapi guru hanya melihat jalan fikiran yang disampaikan oleh Peserta didik, pendapat Peserta didik, serta memotivasi Peserta didik untuk mengeluarkan pendapat mereka, dan sesekali guru tidak boleh tidak menghargai pendapat Peserta didik, sesekalipun pendapat Peserta didik tersebut salah menurut guru (Yamin, 2007 dalam Sabaruddin, 2019).

Sedangkan menurut Syafi'udin dalam Pristiwanto (2016) metode pemecahan masalah merupakan metode pengajaran yang digunakan guru untuk mendorong Peserta didik mencari dan menemukan serta memecahkan persoalanpersoalan. Pemecahan masalah dilakukan dengan cara yang ilmiah. Artinya, mengikuti kaidah keilmuan, seperti yang dilakukan dalam penelitian ilmiah. Oleh sebab itu, dalam memecahkan masalah tidak dilakukan dengan trial and error (coba-coba), melainkan dilakukan secara sistematis dengan menggunakan langkah-langkah: 1) merumuskan masalah dengan memahami, meneliti dan kemudian membatasi masalah, 2) merumuskan hipotesis yang merupakan jawaban sementara bagi masalah yang diajukan dan dibuktikan berdasarkan data dari lapangan, 3) mengumpulkan data dikumpulkan berupa informasi, keterangan, dan barang bukti sesuai dengan yang dibutuhkan dengan melakukan wawancara, 
angket, studi dokumentasi, dan sebagainya, 4) menyimpulkan hasil pengolahan atau analisis data dapat dihasilkan kesimpulan.

Tujuan utama dalam pemecahan masalah diantaranya adalah untuk memperjelas dan memperkuat konsep-konsep, prinsip, hukum bidang studi. Kedua untuk meningkatkan kompetensi Peserta didik dalam keterampilan intelektual, strategi dan prosedur sehingga dapat menampilkan perkembangan intelektual (Selvaratnan, Canagaratna 2008 dalam Sabaruddin, 2019). Keberhasilan pemecahan masalah menurut Lee (Toth, Z., dan Sebestyen. 2009 dalam Sabaruddin, 2019) ditentukan oleh tiga variabel yang masing-masing terdapat dua variabel.

1. Pengetahuan

a. Pengetahuan khusus: pengetahuan yang berkaitan langsung dengan masalah.

b. Pengetahuan tidak spesifik yang relevan: pengetahuan yang berhubungan dengan area subjek masalah.

\section{Keterkaitan}

a. Keterkaitan konsep: keterkaitan antara konsep-konsep yang terlibat dalam pemecahan masalah.

b. Ide asosiasi: hubungan antara informasi yang diambil dari struktur pengetahuan yang ada dan faktor eksternal

3. Masalah keterampilan

a. Masalah keterampilan menerjemah: kemampuan untuk memahami, menganalisis, menafsirkan dan menetapkan soal yang diberikan.

b. Pengalaman sebelum pemecahan masalah: pengalaman sebelumnya dalam menyelesaikan masalah yang sama.

Pemecahan masalah dapat dipandang sebagai suatu proses dimana pembelajaran menemukan perpaduan rumus, aturan dan konsep yang sudah dipelajari sebelumnya dan selanjutnya menerapkannya untuk memperoleh cara pemecahan pada situasi atau keadaan baru, secara demikian juga merupakan proses belajar yang baru. Berdasarkan pengertian tersebut di atas, maka dapat disimpulkan bahwa karakteristik pembelajaran pemecahan masalah yaitu:

1. Belajar menemukan

2. Aturan, rumus, konsep dan pengetahuan terdahulu

3. Memperoleh cara pemecahan

4. Situasi baru

5. Proses belajar baru

Selain itu Peserta didik mampu untuk menggunakan suatu prinsip dan aturan umum dari pengalaman memecahkan masalah. Berdasarkan pengertian di atas, maka melalui pembelajaran pemecahan masalah memberikan Peserta didik kemampuan memecahkan masalah melalui pengalaman secara nyata. Selain itu, 
melalui pembelajaran pemecahan masalah memberikan kemampuan kepada setiap Peserta didik dalam memecahkan masalah dengan cepat, otomatis, efisien dan efektif.

Metode pemecahan masalah (problem solving) dapat diartikan sebagai rangkaian aktivitas pembelajaran yang menekankan kepada proses penyelesaian masalah yang dihadapi secara ilmiah (Sanjaya \& Wina, 2006). Sanjaya berrpendapat bahwa terdapat tiga ciri utama dari metode pemecahan masalah yaitu:

1. Pemecahan masalah (problem solving) merupakan rangkaian aktivitas pembelajaran, artinya dalam implementasi pemecahan masalah ada sejumlah kegiatan yang harus dilakukan Peserta didik mulai dari aktif berfikir, berkomunikasi, mencari dan mengolah data, dan akhirnya menyimpulkan.

2. Aktivitas pembelajaran diarahkan untuk menyelesaikan masalah yang terjadi. Problem solving menempatkan masalah sebagai kata kunci dari proses pembelajaran. Artinya, tanpa masalah yang ada maka tidak mungkin ada proses pembelajaran.

3. Pemecahan masalah dilakukan dengan menggunakan pendekatan berpikir secara ilmiah. Berpikir dengan menggunakan metode ilmiah adalah proses berpikir deduktif dan induktif. Proses berpikir ini dilakukan secara sistematis dan empiris. Sistematis artinya berpikir ilmiah dilakukan melalui tahapantahapan tertentu; sedangkan empiris artinya proses penyelesaian masalah didasarkan pada data dan fakta yang jelas.

Dalam penerapan model pemecahan masalah didalam kelas masih terdapat kekurangan diantaranya beberapa pokok bahasan sangat sulit untuk menerapkan pembelajaran, misalnya terbatasnya alat-alat laboratorium menyulitkan Peserta didik untuk melihat dan mengamati serta akhirnya dapat menyimpulkan kejadian atau konsep tersebut, Memerlukan alokasi waktu yang lebih panjang dibandingkan dengan pendekatan pembelajaran yang lain, serta Peserta didik terkadang merasa bosan dengan aplikasi matrik berbentuk masalah sehari-hari yang terlihat sulit untuk diselesaikan. (Sabaruddin, 2019)

\section{KETERAMPILAN BERFIKIR KRONOLOGIS PESERTA DIDIK}

Pembelajaran kronologi merupakan salah satu tujuan yang penting dalam pembelajaran sejarah karena urutan peristiwa menjadi kunci pokok dalam memahami masa lampau dan masa sekarang. Karena suatu fenomena dalam sejarah tidak akan bisa dipahami secara utuh apabila kita tidak mengetahui hubungan kausalitas antara peristiwa satu dengan lainnya. Ditambah lagi apabila kumpulan peristiwa-peristiwa yang akan dikaji tidak disusun secara berurutan (kronologis) sesuai waktu peristiwa tersebut terjadi. Inilah yang membuat kronologi sangat penting dalam pembelajaran sejarah (Antopani, 2017). 
Pemahaman tentang sebuah kronologi sejarah tidak dapat dipisahkan juga dari pemahaman mengenai konsep ruang dan waktu. Terdapat beberapa aspek penting dalam sebuah kronologi sejarah yaitu ruang, jalannya peristiwa, waktu, waktu pararel. Aspek pertama yaitu ruang yang merupakan tempat terjadinya suatu peristiwa dalam garis waktu. Kedua adalah lama berjalannya peristiwa, yang berarti panjangnya waktu di antara dua tokoh, dua peristiwa, dua periode. Selanjutnya adalah yang mempunyai pengertian periode selama suatu ide, agama, filosofi atau pergerakan mengambil bentuk nyata. Dan yang terakhir adalah waktu pararel, yaitu perkembangan-perkembangan yang pararel terjadi secara serentak dalam sejarah. Berpikir kronologis adalah kemampuan untuk mengidentifikasi waktu masa lalu, hubungannya dengan masa sekarang dan masa yang akan datang serta memahami urutan waktu dalam peristiwa sejarah yang kemudian disusun secara kronologis (Kochar, 2008). Nash dan Phenix berpendapat bahwa Kemampuan berpikir kronologis ini mencakup kemampuan untuk membangun dari pengertian atas waktu (masa lalu, sekarang dan masa datang), untuk dapat mengidentifikasi urutan waktu atas setiap kejadian, mengukur waktu kalender, menginterpretasikan dan menyusun garis waktu, serta menjelaskan konsep kesinambungan sejarah dan perubahannya (Nash dan Phenix dalam Tarunasena, 2008).

Berdasarkan pendapat di atas, berpikir kronologis merupakan bagian dari berpikir kesejarahan. Kemampuan awal untuk mengidentifikasi konsep ruang, waktu, dan peristiwa merupakan modal berharga bagi peserta didik untuk mengembangkan kemampuan berpikir sejarah ke tingkat yang lebih kompleks. Berpikir kronologis dalam pembelajaran sejarah sangatlah penting karena mengacu pada konsep ruang dan waktu. Sejarah akan mengajarkan peristiwa dan kejadian yang telah terjadi sehingga konsep tersebut sangat diperlukan untuk menghindari adanya kesalahan dalam proses pembelajaran. Kronologis merupakan sebuah kurun waktu atau peristiwa yang terjadi secara beruntun berdasarkan urutan waktu terjadinya.

Berdasarkan pemaparan di atas, berpikir kronologis mencakup kemampuan peserta didik untuk mengidentifikasi waktu di masa lalu, keterhubungannya dengan masa sekarang dan dapat memperkirakan dampaknya di masa yang akan datang. Kemampuan berpikir kronologis dapat membantu peserta didik untuk memahami fenomena sejarah yang dikaji. Proses rekonstruksi dari peristiwa-peristiwa sejarah akan lebih cepat dipahami apabila peserta didik sudah mampu mengetahui aspek-aspek dalam sebuah periodisasi sejarah yang disusun secara kronologis. Selain itu peserta didik juga mampu menjelaskan satu peristiwa sejarah secara beruntut sesuai dengan kejadian masa lalu berdasarkan sumber didapatkan. 


\section{KEUNTUNGAN MENGGUNAKAN METODE PEMECAHAN MASALAH (PROBLEM SOLVING) DALAM PEMBELAJARAN SEJARAH}

Metode Pemecahan Masalah tidak hanya dapat membantu meningkatkan keterampilan berfikir kronologis saja, tetapi terdapat banyak keuntungan lain apalagi guru mampu menerapkan dalam pembelajaran dikelas. Pengetahuan yang diperoleh dengan belajar metode pemecahan masalah (problem solving) akan bertahan lama, mempunyai efek transfer yang lebih baik dan meningkatkan Peserta didik dan kemampuan berpikir secara bebas. Secara umum belajar metode pemecahan masalah (problem solving) ini melatih keterampilan kognitif untuk menemukan dan memecahkan masalah tanpa pertolongan orang lain. Selain itu, belajar penemuan membangkitkan keingintahuan Peserta didik, memberi motivasi untuk bekerja sampai menemukan jawaban (Syafi'udin, 2002 dalam Pristiwanto, 2016)

Metode pemecahan masalah ini akan memiliki dampak yang lebih besar apabila di divariasikan dengan metode diskusi, seperti hasil penelitian yang dilakukan oleh Suwito Eko Purnomo (2012), dimana dikatakan bahwa metode pemecahan masalah yang divariasikan dengan metode diskusi bukan hanya mampu meningkatkan wawasan dan kemampuan Peserta didik dalam memahami peristiwa sejarah dengan berbagai persoalannya, melainkan mampu meningkatkan kemampuan dalam memahami makna dari setiap peristiwa sejarah bagi kepentingan masa kini dan yang akan datang. Bahkan, pengetahuan dan wawasannya dapat bertahan lama karena diperoleh melalui aktifitas nyata dari diskusi tersebut. Itulah salah satu kelebihan metode Pemecahan masalah (problem Solving) apabila di variasikan dengan metode diskusi.

\section{PENUTUP}

Penggunaan metode problem solving dalam pembelajaran sejarah memungkinkan Peserta didik untuk dapat membangun sendiri pengetahuan yang diperolehnya dengan cara mencari fakta-fakta atau bukti sejarah melalui buku dan sumber internet. Selain itu penggunaan metode problem solving dalam pembelajaran sejarah dapat melatih peserta didik dalam menulis sejarah, melihat realitas sosial beserta segala permasalahan yang ada didalamya serta melatih Peserta didik untuk berpikir kritis dengan mengemukakan pendapatnya serta meningkatkan keterampilan berfikir kritis sehingga Peserta didik dapat memiliki kesadaran sejarah yang akan membuat Peserta didik lebih memahami terhadap nilai-nilai kehidupan. Pembelajaran sejarah sendiri harus memberikan kesempatan kepada peserta didik untuk mengembangkan pengetahuan dan pemahamannya mengenai peristiwa sejarah dan kemampuan berpikir dalam sejarah. 


\section{DAFTAR PUSTAKA}

Antopani, H. (2017, Juli 10). Penggunaan Media Time Line Untuk Meningkatkan Kemampuan Berfikir Kronologis Siswa Dalam Pembelajaran Sejarah. Retrieved April 18, 2020, from Repository Indonesia University Of Education: http://repository.upi.edu/23540/

Hudaidah. (2014). Historical Thinking, Keterampilan Berpikir Utama Bagi Mahasiswa Sejarah. Criksetra Jurnal Pendidikan Sejarah, Vol. 3, No. 1.

Kasmadi, \& Hartono. (1996). Model-Model Dalam Pembelajaran Sejarah. Semarang: IKIP Semarang Press.

Khairani, I., \& Safitri, R. (2017). Penerapan Metode Pembelajaran Problem Solving Untuk Meningkatkan Hasil Belajar Peserta Didik Pada. Jurnal Pendidikan Sains Indonesia, Vol. 5, No. 2, Hal. 32-40.

Kochar. (2008). Pembeajaran Sejarah Teaching History. Jakarta: Grasindo.

Pramono, S. E. (2012). Perbaikan Kesalahan Konsep Pembelajaran Sejarah Melalui Metode Pemecahan Masalah dan Diskui. Paramita, Vol. 22, No. 2. Hal. 238-248.

Pristiwanto. (2016). Penerapan Metode Pemecahan Masalah (Problem Solving) Untuk Meningkatkan Pemahaman Siswa Tentang Komponen Peta. Wahana Pedagogika, Vol. 2, No. 2. Hal. 127-134.

Sabaruddin. (2019). Penggunaan Model Pemecahan Masalah Untuk Meningkatkan Kemampuan Berfikir Analisis Peserta Didik Pada Materi Gravitasi Newton. Lantanida Journal, Vol. 7, No. 1, 1-100.

Sanjaya, \& Wina. (2006). Strategi Pembelajaran Berorientasi Standar Pendidikan. Jakarta: Kencana Prenada Media Group.

Susanto, H., \& Akmal, H. (2019). Media Pembelajaran Sejarah Era Teknologi Informasi. Banjarmasin: PSP Sejarah FKIP ULM.

Tarunasena. (2008). Upaya Meningkatkan Kualitas Pembelajaran Sejarah Melalui Historical Thinking. Bandung: Jurusan Pendidikan Sejarah FPIPS UPI.

Trianto. (2010). Mendesain Model Pembelajaran Inovatif, Progresif, Konsep Landasan, dan Implementasinya pada Kurikulum Tingkat Satuan Pendidikan (KTSP). Jakarta: Kencana.

Zahro, M., Sumardi, \& Marjono. (2017). The Implementation Of The Character Education In History Teaching. Jurnal Historica, Volume 1, Issue 1, 